
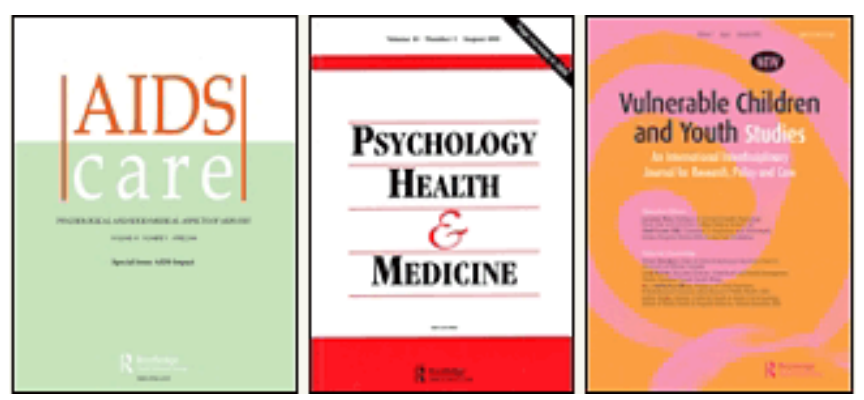

\title{
Late diagnosis of HIV in Europe: definitional and public health challenges
}

\begin{tabular}{|r|l|}
\hline Journal: & $\begin{array}{l}\text { AIDS Care - Psychology, Health \& Medicine - Vulnerable Children } \\
\text { and Youth Studies }\end{array}$ \\
\hline Manuscript ID: & AC-2008-01-0033.R1 \\
\hline Journal Selection: & AIDS Care \\
\hline Keywords: & HIV, Diagnosis, Health services, Access, Europe \\
\hline \multicolumn{2}{|r}{} \\
\hline
\end{tabular}

\section{s scholarONE \\ Manuscript Central}


Title: Late diagnosis of HIV in Europe: definitional and public health challenges

Short title for page headings: HIV and late diagnosis

\section{Authors:}

A Adler, $\mathrm{PhD}, \mathrm{MSc}$

S Mounier-Jack, MSc, MBA

R J Coker, MD, FRCP

\section{Department and Institution}

Department of Public Health and Policy, London School of Hygiene and Tropical Medicine, Keppel Street, London WC1E 7HT, UK

Correspondence to: richard.coker@1shtm.ac.uk

\section{Summary:}

With universal access to antiretroviral therapy (ART), people can access effective treatment but are only able to benefit from these advances if they are aware of their status and are effectively accessing testing services. Although it was anticipated in the mid-1990s that the availability of ART would lead to earlier testing, this trend has not been observed in practice, with stagnant or even increasing rates of late diagnosis in Europe. Ahead of a gathering of key European stakeholders in Brussels in November 2007, we reviewed definitions of late diagnosis and approaches to surveillance of late HIV diagnosis in Europe. We found that there is no common or consistent reporting of late diagnosis across Europe and that the multiplicity of definitions for late diagnosis is likely proving a hindrance to providing information on the magnitude of the problem, determining trends, and informing understanding of reasons for changes in trends. We also show that existing evidence points to high rates of late diagnosis across Europe - between $15 \%$ and $38 \%$ of all HIV cases- and concur that trends that are increasing or at best stagnant. We identify risk factors that are associated with individuals being more likely to present late and we explore the reasons for late presentation. We reflect on the need to review surveillance and testing policies, notably in relation for population groups that are heavily represented in late presenters and make recommendations for a coherent, cross-European approach to surveillance and monitoring in order to support improvements in service provision and, ultimately, public health. 


\section{Keywords:}

HIV

Health Services

Diagnosis

Access

Europe

\section{Word count: 2888}

\section{Funding:}

This research was undertaken through an unrestricted educational grant from CMGRP Belgium SCRL

The introduction of effective antiretroviral treatment (ART) in the mid 1990s heralded a new era in the management of HIV/AIDS, offering the potential for improved health for individuals coupled with profound public health gain for society. The incentives for HIV-seropositive individuals to know their status appeared to be substantial. However, rates of undiagnosed cases remain high in Europe having been estimated at $30 \%$ by the European Centre for Disease Prevention and Control in 2006 (ECDC, 2006). Late diagnosis of HIV can be defined as presenting for treatment for HIV at a time after it may have been beneficial to start treatment.

Late presentation is detrimental to health for individuals, resulting in increased morbidity and mortality, and for public health because of the increased potential for transmission from individuals unaware of their HIV status. It has been shown that earlier diagnosis reduces short term mortality by $56 \%$ overall and heterosexually acquired AIDS mortality by 32\%,(Chadborn, Delpech, Sabin, Sinka, \& Evans, 2006) and that as much as 77\% of all AIDS-related deaths could be late presenters (Ciancio, Forde, Dougan, Chadborn, \& Delpech, 2006). In 2007, a British HIV Association (BHIVA) mortality survey showed that the impact on death of late diagnosis was as much as 35\% of HIV-related deaths in HIV infected people and $24 \%$ of total deaths in HIV infected people (BHIVA, 2006). Cohort analyses have reported that over three years, compared with a baseline CD4 of less than 50/ $\mu 1$, people initiating ART with CD4 counts of between $50 / \mu 1$ and $99 / \mu 1$ had 0.74 times the 
risk of death and those who began ART with CD4 counts of 200-349/ $\mu$ l had 0.24 times the risk of death (Egger et al., 2002). Similarly, patients who began treatment with CD4 counts less than 50/ $\mu 1$ had 70 deaths per 1000 person-years while those who initiated treatment with CD4 counts greater than 200 had only 3.2 deaths per 1000 person-years (Jensen-Fangel et al., 2004). Patients starting ART before their CD4 count fell below 200/ $\mu 1$ had similar mortality rates to the general population not infected with HIV (Jensen-Fangel et al., 2004).

Late diagnosis also has a major public health impact. Early detection reduces transmission, because of both the adoption of changes in risk behaviour, (Lansky, Nakashima, \& Jones, 2000) (Gorbach, Drumright, Daar, \& Little, 2006) (Inciardi, Surratt, Kurtz, \& Weaver, 2005) (Patterson, Shaw, \& Semple, 2003) (Brogly, Bruneau, Lamothe, Vincelette, \& Franco, 2002) as well as a reduced viral load resulting from ART and thus reduced transmission (Quinn et al., 2000) (Vernazza et al., 2000) (Cu-Uvin et al., 2000; Fiore et al., 2003; Graham et al., 2007); (Hessol et al., 2007) (Kayitenkore K, Bekan B, Rufagari J, \& et al., 2006) (Porco et al., 2004) (Katz, Davis, \& Findlay, 2002) Late diagnosis also has economic implications, increasing costs for health services and society (Krentz, Auld, \& Gill, 2004) (Samrawickrama A et al., 2007).

The purpose of this paper is to review approaches to determining late diagnosis of HIV across Europe and to assess the scope of late diagnosis in the region and explore its underlying determinants.

\section{METHODS}

In November 2007, we conducted a search of Pubmed and Google using the search terms "late diagnosis" or "late presentation" AND "HIV" or "Human Immunodeficiency Virus", and "Europe". We searched for articles published after 1997 (the advent of ART). We also reviewed the references of identified articles and included in our review those relevant. We identified 63 relevant articles, 29 of which gave a definition for late presentation. Owing to the limited information in this area, we also included key studies from the US, Australia and New Zealand because they were deemed 
relevant to the definitional issue and because of similarities in their experience of the HIV epidemic and their health systems. This gave us a total of 37 definitions. Rates are only presented for Europe.

Additionally in September 2007 we surveyed 33 European countries (European Union, Norway, Switzerland, Belarus, Moldavia, Russian Federation and Ukraine) and requested countries' collaborators in Public Health institutions to provide us with national data on late diagnosis. Collaborators were identified through the WHO Euro office and through the London School of Hygiene and Tropical Medicine network. Through our European survey, 24 countries responded out of 33 contacted. Out of these 24,22 provided us with some information on late diagnoses reported and 13 provided specific data on late diagnosis indicators.

\section{RESULTS}

\section{Definitions and Incidence of Late Diagnosis}

We found that there was no standard definition of late diagnosis. Through our review we identified nine different definitions of late diagnosis, grouped thematically in three ways. These definitions are shown in Table 1 and Table 2.

1) Definitions based on time,

2) Definitions based on CD4 counts, and

3) Definitions based on clinical presentation.

Definitions based on time from HIV diagnosis to AIDS diagnosis range from one year to one month. Researchers that used baseline CD4 count as the definition ranged between $50 / \mu 1$ and $350 / \mu 1$. The most frequent definition was a CD4 count of less than 200/ $\mu 1$. This was used in nine of 37 studies. The next most frequent definition was HIV diagnosis within 3 months of AIDS diagnosis. This definition was used in eight out of 37 studies. Although in theory all of these definitions are based on the same notion - being diagnosed with HIV when treatment should have already been initiated there are implications beyond the clinical in differences in approach. If allocation of resources is 
informed by definitions of late diagnosis, then a late diagnosis with CD4 count $<350 / \mu 1$, depending on the guidelines followed, may have different resource implications from when a late diagnosis is dependent on a diagnosis of AIDS. Similarly, there are apparent differences in public health consequences dependent on different definitions of late diagnoses. Our understanding of the magnitude of the challenge of late presentation and policy responses constructed to respond to that challenge may vary depending on the definition used.

We could not detect any patterns of definitions of late diagnosis by geographical region and our European survey also showed the high variability in definitions of late diagnosis between the 22 responding countries. In some cases the same researchers used different definitions in different studies. For example, in 2000, Girardi et al used the definition of presenting with HIV within three months of initial AIDS diagnosis (Girardi, Sampaolesi, Gentile, Nurra, \& Ippolito, 2000). In 2004,

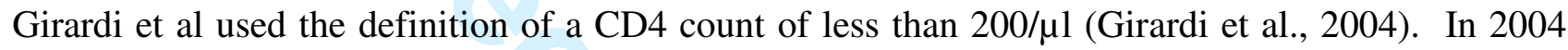
Sabin et al used the definition of CD4 count less than 50/ $\mu 1$, whilst in 2006 they defined late diagnosis as being diagnosed with HIV within six months of being diagnosed with AIDS (Sabin et al., 2004) (Chadborn, Delpech, Sabin, Sinka, \& Evans, 2006).

The definition of late diagnosis will have an effect upon determinations of the incidence of late diagnosis. With definitions associated with greater immunological competence, more individuals will be included. As a result, studies in the UK that use a CD4 count below 200/ $\mu 1$ show incidence of late diagnosis to be around 30\%(Health Protection Agency, 2006). A study that used a CD4 count under 50/ $\mu 1$ showed an incidence around 15\% (Sabin et al., 2004). Incidence of late diagnosis in Europe is shown in Table 2.

Another complicating factor is the denominator used when determining late diagnosis incidence. Some studies report the number of individuals presenting late as a proportion of all individuals with HIV or AIDS, while others report individuals presenting late with the denominator being only people who have developed AIDS. In our review, we identified $25(68 \%)$ studies that use as the denominator HIV cases. Twelve studies used AIDS cases as the denominator. See Table 1. We could detect no pattern by countries. Clearly this is an important distinction as a proportion of HIV cases may never become AIDS cases. As a result, using HIV cases as a denominator will result in a smaller percentage of individuals who are late presenters than where the denominator is AIDS cases. 
Overall incidence of late presentation of HIV has been reported between $15 \%$ to $38 \%$ of all HIV cases. When the denominator is the number of AIDS cases, the overall incidence is higher, up to $53 \%$. Results are shown from the literature review in Table 2 and from our survey in Table 3.

Studies show that the proportion of people diagnosed late with HIV within the total HIV population is increasing. One study from the UK showed that people had 2.4 times the odds of presenting with AIDS in 1998-1999 than in 1982-1995 (F. M. Burns, Fakoya, Copas, \& French, 2001). In Italy a study shows late presentation increasing from 13.8 in 1993 to $32.5 \%$ in 2000 (Castelnuovo et al., 2003). A similar pattern has been found in late presenters in total AIDS cases. This pattern was found in Sweden, where late presentation increased from 22\% in 1996 to 58\% in 2002 (Brannstrom, Akerlund, Arneborn, Blaxhult, \& Giesecke, 2005). In Spain, late diagnosis was shown to increase from 24\% in 1994 to 35\% in 1998 to 2000 (Castilla et al., 2002), in France late diagnosis increased from 15.6\% before 1996 to $41.9 \%$ after 1996 (Baratin et al., 2004) whilst in Italy two studies show late diagnosis increasing from 16\% in 1995 to 36.6\% in 1998 (Girardi, Sampaolesi, Gentile, Nurra, \& Ippolito, 2000), from 19.95\% in 1996 to 50.47\% in 2002 (Longo, Pezzotti, Boros, Urciuoli, \& Rezza, 2005).

The proportion of people presenting late as a proportion of all HIV cases was found to be stable in one study from the UK, (Sabin et al., 2004) and was found to be decreasing in one study from France (Delpierre et al., 2007) and in the UK in men who have sex with men (MSM), from $38 \%$ in 1993 to $25 \%$ in 2002 (Chadborn et al., 2005; Easterbrook et al., 2000).

\section{Who is at Risk of late Diagnosis}

In order to address the problem of late diagnosis, it is important to understand who is at risk of presenting late and to explore the underlying causes of late presentations. Across a variety of studies, the common characteristics of late diagnosis included migrant status, being older, being heterosexual, living in low HIV prevalence areas, and being male.

In most studies migrants were at greater risk of presenting late than people born in the country of study. This pattern was found in Sweden (Brannstrom, Akerlund, Arneborn, Blaxhult, \& Giesecke, 2005), the UK (Boyd et al., 2005; Sabin et al., 2004; Sullivan, Curtis, Sabin, \& Johnson, 2005) 
France (Delpierre et al., 2007), Spain (Castilla et al., 2002) Italy, (Girardi et al., 2004; Girardi et al., 2001; Girardi, Sampaolesi, Gentile, Nurra, \& Ippolito, 2000; Longo, Pezzotti, Boros, Urciuoli, \& Rezza, 2005), the United States (Hogan et al., 2001) and Australia (Hocking, Rodger, Rhodes, \& Crofts, 2000; McDonald, Li, Dore, Ree, \& Kaldor, 2003). Only two studies, from France, (Baratin et al., 2004; Rotily, Bentz, Pradier, Obadia, \& Cavailler, 2000) found no difference in rates of late diagnosis between migrants and non-migrants. In France, co-incident AIDS and HIV diagnosis has decreased in African migrants since 2000, from $71 \%$ to $55 \%$ (Institut National de Veille Sanitaire, 2006). Reasons cited for why migrants are more likely to present late are related to either real or imagined barriers to HIV prevention and care and may also involve cultural, linguistic and socioeconomic barriers (Hamers \& Downs, 2004). Individuals may also feel stigmatised more than non-migrants (F. M. Burns, Imrie, Nazroo, Johnson, \& Fenton, 2007; Erwin, Morgan, Britten, Gray, \& Peters, 2002; Hamers \& Downs, 2004).

Burns et al. found that Africans living in the UK are more likely to get tested for HIV than nonAfricans (40\% of Africans versus 12-13\% of non-Africans) (F. Burns et al., 2005). However, this study was unable to find a correlation between perceived risk of HIV and HIV testing. Africans living in the UK may be less likely to present for HIV testing because they do not feel that they are at risk of acquiring HIV(Barry et al., 2002; Boyd et al., 2005; Erwin, Morgan, Britten, Gray, \& Peters, 2002). One study showed that $41 \%$ of Africans are likely to have an HIV test because of perceived risk compared to $72 \%$ of non-Africans (Boyd et al., 2005). Those that do suspect they are at risk are more likely to wait up to 12 months before getting HIV tests than non-Africans (Erwin, Morgan, Britten, Gray, \& Peters, 2002). Africans in the UK may meet other barriers to HIV testing. As English is not the first language of many migrants, messages may not be heard, and Africans living in the UK may not fully understand what their rights to care are under the UK National Health Service (F. M. Burns, Imrie, Nazroo, Johnson, \& Fenton, 2007). Some Africans may also be in the country with uncertain migrant status and may not be eligible for NHS care (Dodds, Mercey, Parry, \& Johnson, 2004) (Erwin, Morgan, Britten, Gray, \& Peters, 2002).

Many studies have also shown a lack of advocacy for HIV infected Africans living in the UK, (F. M. Burns, Imrie, Nazroo, Johnson, \& Fenton, 2007; Dodds, Mercey, Parry, \& Johnson, 2004; Erwin, Morgan, Britten, Gray, \& Peters, 2002) combined with much negative publicity about UK taxpayers having to support migrants in the UK who are infected with HIV or other diseases, so-called 'health 
tourists', issues that may be impacting on willingness to get tested for HIV (F. M. Burns, Imrie, Nazroo, Johnson, \& Fenton, 2007).

Fear is another factor influencing why many Africans do not seek HIV testing. Two-thirds of Africans in one study reported fear of dying as a major concern (Erwin, Morgan, Britten, Gray, \& Peters, 2002). Stigma plays a major role in people delaying testing, notably because HIV/AIDS is still perceived, in light of the African experience of the disease, as a death sentence (F. M. Burns, Imrie, Nazroo, Johnson, \& Fenton, 2007; Gazzard B on behalf of British HIV Association, 2006). The improved clinical experience for patients in the UK may not have been heard by migrant communities (Dodds, Mercey, Parry, \& Johnson, 2004; Erwin, Morgan, Britten, Gray, \& Peters, 2002). Cultural beliefs, social experience, and scepticism surrounding ART may fuel belief in alternative treatments or fatalistic acceptance (Erwin, Morgan, Britten, Gray, \& Peters, 2002; Erwin \& Peters, 1999). Fear of disclosure may influence some Africans to not get tested (F. M. Burns, Imrie, Nazroo, Johnson, \& Fenton, 2007). Africans tend to tell fewer people about their HIV status. Erwin et al. found that $15 \%$ of Africans did not disclose their status even to close family or friends, compared to $3 \%$ of non-Africans (Erwin, Morgan, Britten, Gray, \& Peters, 2002).

Characteristics other than migrant status are associated with an increased risk of presenting late with HIV. Many researchers have found that living in a region with a low prevalence of HIV increases the risk of late diagnosis. This pattern was found in the UK where the highest rates of late diagnosis are from outside London (Chadborn et al., 2005). Similar patterns have been reported from Spain (Castilla et al., 2002), Italy (Longo, Pezzotti, Boros, Urciuoli, \& Rezza, 2005) and Australia (Hocking, Rodger, Rhodes, \& Crofts, 2000). Possible explanations for these patterns are that either there is less perceived risk in areas with low prevalence, or greater stigma associated with it (Longo, Pezzotti, Boros, Urciuoli, \& Rezza, 2005).

Most studies show that IDUs have lower rates of late diagnosis. This was shown in Sweden, (Brannstrom, Akerlund, Arneborn, Blaxhult, \& Giesecke, 2005) the UK,(Manavi, McMillan, Ogilvie, \& Scott, 2004) France, (Couturier et al., 1998) Spain, Italy (Castelnuovo et al., 2003; Girardi et al., 2004; Girardi et al., 2001; Girardi, Sampaolesi, Gentile, Nurra, \& Ippolito, 2000; Longo, Pezzotti, Boros, Urciuoli, \& Rezza, 2005), Poland (Rosinska, 2006) and Australia (Hocking, Rodger, Rhodes, \& Crofts, 2000). Only in four studies in France were IDUs found to be more likely 
to be late presenters (Baratin et al., 2004; Delpierre, Cuzin, Lauwers-Cances, Marchou, \& Lang, 2006; Delpierre et al., 2007; Rotily, Bentz, Pradier, Obadia, \& Cavailler, 2000).

Age is another factor that may influence risk of late diagnosis. Nearly all studies in all regions showed that older age, particularly over 40, is associated with increased risk of late diagnosis.

Most studies report that men are more likely to present late. This pattern was found in a large European study, (Giard, Gambotti, Besson, Fabry, \& Vanhems, 2004) in the UK, (Gupta, Gilbert, Brady, Livingstone, \& Evans, 2000; Saul, Erwin, Bruce, \& Peters, 2000) France (Couturier et al., 1998; Delpierre, Cuzin, Lauwers-Cances, Marchou, \& Lang, 2006; Delpierre et al., 2007), Spain (Castilla et al., 2002), Italy (Castelnuovo et al., 2003; Girardi et al., 2004; Girardi et al., 2001; Longo, Pezzotti, Boros, Urciuoli, \& Rezza, 2005), the United States (Duffas, 2006; Mayben et al., 2007; Samet, Freedberg, Savetsky, Sullivan, \& Stein, 2001) and Canada (Krentz, Auld, \& Gill, 2004). Two studies from France (Baratin et al., 2004; Rotily, Bentz, Pradier, Obadia, \& Cavailler, 2000), one pre-ART study in England (Poznansky et al., 1995) and a study in Sweden (Brannstrom, Akerlund, Arneborn, Blaxhult, \& Giesecke, 2005) showed no difference between males and females. Only in one study in England, that used CD4 counts of less than 50/ $\mu$ l as the cut-off for late diagnosis, showed that females more often presented late (Sabin et al., 2004). This difference between males and females likely represents the fact that antenatal testing is routinely offered in Europe. In 2006, 84\% of countries in the WHO European region offered routine testing to pregnant women, including most countries in Northern and Western Europe (Devaux I \& Nardone A, 2007).

Most studies indicate that heterosexuals are at greater risk of late diagnosis than MSM. This was shown in Europe (Giard, Gambotti, Besson, Fabry, \& Vanhems, 2004), in Sweden (Brannstrom, Akerlund, Arneborn, Blaxhult, \& Giesecke, 2005), the UK (Boyd et al., 2005; Gupta, Gilbert, Brady, Livingstone, \& Evans, 2000; Hamers \& Downs, 2004; Manavi, McMillan, Ogilvie, \& Scott, 2004), France (Baratin et al., 2004; Couturier et al., 1998; Delpierre, Cuzin, Lauwers-Cances, Marchou, \& Lang, 2006; Delpierre et al., 2007), Italy (Castelnuovo et al., 2003; Girardi et al., 2001) Poland, (Rosinska, 2006), Canada (Krentz, Auld, \& Gill, 2004) and Australia (McDonald, Li, Dore, Ree, \& Kaldor, 2003). Only in Eastern Europe did it appear that MSM were more likely to present later than heterosexuals (Likatavicius G, Downs A, Alix J, Devaux i, \& Nardone A, 2006). 
Other characteristics associated with late diagnosis included having had a negative test in the past and having children (Delpierre, Cuzin, Lauwers-Cances, Marchou, \& Lang, 2006; Delpierre et al., 2007; Girardi et al., 2004). Higher education was shown to be a risk factor in some studies (Couturier et al., 1998; Longo, Pezzotti, Boros, Urciuoli, \& Rezza, 2005) but protective in another study (Centers for Disease Control and Prevention, 2003) and had no effect in another study (Krentz, Auld, \& Gill, 2004). Having no or only one close friend is associated with increased risk for late testing (Samet, Freedberg, Savetsky, Sullivan, \& Stein, 2001).

\section{DISCUSION}

Late diagnosis of HIV has important individual, public health and economic consequences in Europe. A substantial proportion of people who die from AIDS are late presenters. Our review has shown that varying risk factors such as fear, stigma, lack of knowledge about health services or risk of infection can all influence an individual's choice to seek or not seek HIV diagnosis.

In order to explore the magnitude of late diagnosis in Europe and to promote appropriate prevention and testing policies, it is necessary to understand who is not coming forward for HIV testing. With nine different definitions of late diagnosis and wide differences existing across studies, countries and time, this means that data are not comparable. As a result it is difficult to assess the magnitude or temporal trends of the problem and to develop and monitor policies. Additionally, it appears that little is known of late diagnosis in many European countries, a knowledge gap that needs to be addressed. Standardizing the definition of late diagnosis will facilitate comparative analyses, support evaluations of policy initiatives, and offer insights into what works, where and why.

With global strategic advocacy of universal access to ART, people should be able to access effective treatment. But they can only benefit from advances in treatment if they are aware of their HIV status and are effectively accessing testing services. Although, in the mid 1990s, it was anticipated that the availability of ART would lead to earlier testing, this hope has not been realised in practice broadly, rates of late diagnosis have either remained the same of increased. Confronted with substantial numbers of individuals unaware of their HIV status, there have been calls in a number of countries in Europe for an extension of provider-initiated routine opt-out testing (Hamill et al., 2007) (Delpierre, Cuzin, \& Lert, 2007). On 30 May 2007, WHO and UNAIDS issued new guidance on HIV testing and counselling in health facilities (WHO/UNAIDS, 2007). These recommended 
that HIV testing should normally be performed, much like other routine investigations, unless the patient declines in a number of medical settings such as STI, TB and antenatal clinics. The large numbers of individuals presenting late for diagnosis also has implications for testing policies (in addition to definitional issues) across Europe. By addressing more effectively and earlier the needs of individuals likely to present late, policy makers can offer benefits to both individuals and public health. 
Table 1. Definition of late diagnosis

\begin{tabular}{|c|c|c|c|c|}
\hline Numerator & Region & Denominator & Author & Year \\
\hline \multirow[b]{3}{*}{ Less than one year } & Europe & HIV & Likatavicius et al & 2006 \\
\hline & & HIV & Duffas et al & 2006 \\
\hline & US & HIV & MMWR & 2006 \\
\hline \multirow[b]{3}{*}{ Less than six months } & England & HIV & Sabin et al & 2006 \\
\hline & France & AIDS & Couturier et al & 1998 \\
\hline & Italy & AIDS & Longo et al & 2005 \\
\hline \multirow[b]{8}{*}{ Less than 3 months } & Sweden & AIDS & Brannstrom et al & 2005 \\
\hline & England & AIDS & Easterbrook et al & 2000 \\
\hline & France & AIDS & Couzigou et al & 2007 \\
\hline & France & AIDS & Baratin et al & 2004 \\
\hline & Italy & AIDS & Girardi et al & 2000 \\
\hline & Poland & AIDS & Rosinka & 2006 \\
\hline & Canada & HIV & Krentz et al & 2004 \\
\hline & Australia & AIDS & McDonald et al & 2003 \\
\hline Less than eight weeks & Australia & AIDS & Hocking et al & 2004 \\
\hline \multirow[b]{4}{*}{ Less than 1 month } & Denmark & $\mathrm{HIV}$ & Lohse et al & 2005 \\
\hline & England & HIV & Burns et al & 2001 \\
\hline & Spain & AIDS & Castilla et al & 2002 \\
\hline & Italy & HIV & Castelnuovo et al & 2003 \\
\hline \multirow{4}{*}{$\begin{array}{l}\text { HIV concurrent with } \\
\text { AIDS }\end{array}$} & Poland & $\mathrm{HIV}$ & Podlasin et al. & 2006 \\
\hline & England & HIV & Saul et $\mathrm{al}^{*}$ & 2006 \\
\hline & US & AIDS & Hogan et al & 2001 \\
\hline & France & HIV & Rotily et al & 2000 \\
\hline \multirow{2}{*}{$\begin{array}{l}\text { CD4 count less than } \\
350\end{array}$} & England & HIV & Saul et $\mathrm{al}^{*}$ & 2000 \\
\hline & US & HIV & Mayben et al & 2007 \\
\hline \multirow{10}{*}{$\begin{array}{l}\text { CD4 count less than } \\
200\end{array}$} & & HIV & Health Protection Agency & 2006 \\
\hline & & HIV & Brown et al & 2006 \\
\hline & & HIV & Sullivan et al & 2005 \\
\hline & & HIV & Chadborn et $\mathrm{al}^{* *}$ & 2005 \\
\hline & & HIV & Manavi et al ${ }^{\star \star *}$ & 2004 \\
\hline & UK & HIV & Gupta et $\mathrm{al}^{\star *}$ & 2000 \\
\hline & & HIV & Delpierre et al & 2007 \\
\hline & France & HIV & Delpierre et al & 2006 \\
\hline & Italy & HIV & Girardi et al & 2004 \\
\hline & US & HIV & Samet et al & 2001 \\
\hline \multirow[b]{2}{*}{ CD4 count less than 50} & Spain & HIV & Santos & 2005 \\
\hline & UK & HIV & Sabin et al & 2004 \\
\hline
\end{tabular}

\footnotetext{
* Test positive with CD4<350 or with AIDS defining illness

** England and Wales

${ }^{* * *}$ Scotland
} 
Table 2 Incidence of late diagnosis

\begin{tabular}{|c|c|c|c|c|c|c|c|}
\hline Country & Incidence & $\begin{array}{l}\text { Special } \\
\text { Population }\end{array}$ & Definition & Denominator & $\begin{array}{l}\text { Sample } \\
\text { Size }\end{array}$ & Author & Date \\
\hline \multirow{15}{*}{ UK } & $34 \%$ & Overall & \multirow{5}{*}{ CD4<200 } & \multirow{5}{*}{ HIV } & 7325 & \multirow{5}{*}{$\begin{array}{l}\text { Health } \\
\text { Protection } \\
\text { Agency }\end{array}$} & \multirow{5}{*}{2006} \\
\hline & $23 \%$ & MSM & & & & & \\
\hline & $28 \%$ & IDU & & & & & \\
\hline & \multirow{2}{*}{$\begin{array}{l}37 \% \\
47 \%\end{array}$} & $\begin{array}{l}\text { Hetero } \\
\text { Females }\end{array}$ & & & & & \\
\hline & & $\begin{array}{l}\text { Hetero } \\
\text { Males }\end{array}$ & & & & & \\
\hline & $23 \%$ & 8 & $\begin{array}{l}\text { HIV with } \\
\text { AIDS }\end{array}$ & HIV & 450 & Saul et $\mathrm{al}^{* * *}$ & 2006 \\
\hline & $15 \%$ & & CD4<50 & HIV & 719 & Sabin et al & 2004 \\
\hline & $33 \%$ & 8 & CD4<200 & HIV & 977 & Sullivan et al & 2005 \\
\hline & $38 \%$ & ANC & \multirow{2}{*}{ CD4<200 } & HIV & 13 & \multirow{2}{*}{ Manavi et al ${ }^{*}$} & \multirow{2}{*}{2004} \\
\hline & $34 \%$ & GUM & & HIV & 189 & & \\
\hline & $31 \%$ & MSM & CD4<200 & HIV & 14158 & $\begin{array}{l}\text { Chadborn et } \\
\mathrm{al}^{* \star}\end{array}$ & 2005 \\
\hline & $35 \%$ & Africans & \multirow[b]{2}{*}{$<1$ month } & \multirow[b]{2}{*}{ HIV } & 143 & \multirow[b]{2}{*}{ Burns et $a l^{* \star *}$} & \multirow[b]{2}{*}{2001} \\
\hline & $13 \%$ & $\begin{array}{l}\text { Non- } \\
\text { Africans }\end{array}$ & & & 243 & & \\
\hline & $23 \%$ & & $\begin{array}{l}\text { CD4<350 or } \\
\text { AIDS } \\
\text { diagnosis }\end{array}$ & HIV & 450 & Saul et $\mathrm{al}^{* \star \star}$ & 2000 \\
\hline & $37 \%$ & & CD4<200 & HIV & 1204 & Gupta et al ${ }^{+}$ & 2000 \\
\hline \multirow{3}{*}{ France } & $33 \%$ & & CD4<200 & HIV & 1077 & Delpierre et al & 2007 \\
\hline & $38 \%$ & & CD4<200 & HIV & 372 & Delpierre et al & 2006 \\
\hline & $27 \%$ & & $\begin{array}{l}\text { HIV with } \\
\text { AIDS }\end{array}$ & HIV & 825 & Rotily et al & 2000 \\
\hline \multirow[b]{2}{*}{ Italy } & $29 \%$ & & CD4<200 & HIV & 968 & Girardi et al & 2004 \\
\hline & $33 \%$ & & $<1$ month & HIV & 3483 & $\begin{array}{l}\text { Castelnuovo et } \\
\text { al }\end{array}$ & 2003 \\
\hline Denmark $^{+}$ & $15 \%$ & & $<1$ month & HIV & 3941 & Lohse et al. & 2005 \\
\hline Poland & $36 \%$ & & $<3$ months & AIDS & 803 & Rosinka & 2006 \\
\hline Sweden & $45 \%$ & & $<3$ months & AIDS & 487 & $\begin{array}{l}\text { Brannstrom et } \\
\text { al }\end{array}$ & 2005 \\
\hline \multirow{4}{*}{ France } & $42 \%$ & & $<3$ months & AIDS & 1885 & Couzigou et al & 2007 \\
\hline & $30 \%$ & & $<3$ Months & AIDS & 1901 & Baratin et al & 2004 \\
\hline & $19 \%$ & & $<6$ months & AIDS & 359 & Couturier et al & 1998 \\
\hline & $28 \%$ & & $<1$ month & AIDS & 30778 & Castilla et al & 2002 \\
\hline \multirow{2}{*}{ Italy } & $37 \%$ & & $<6$ months & AIDS & 16977 & Longo et al & 2005 \\
\hline & $25 \%$ & & $<3$ months & AIDS & 968 & Girardi et al & 2000 \\
\hline
\end{tabular}

*Scotland **England and Wales ***England + Does not mention late diagnosis 
Table 3 Incidence of late diagnosis in Europe (LSHTM survey results)*

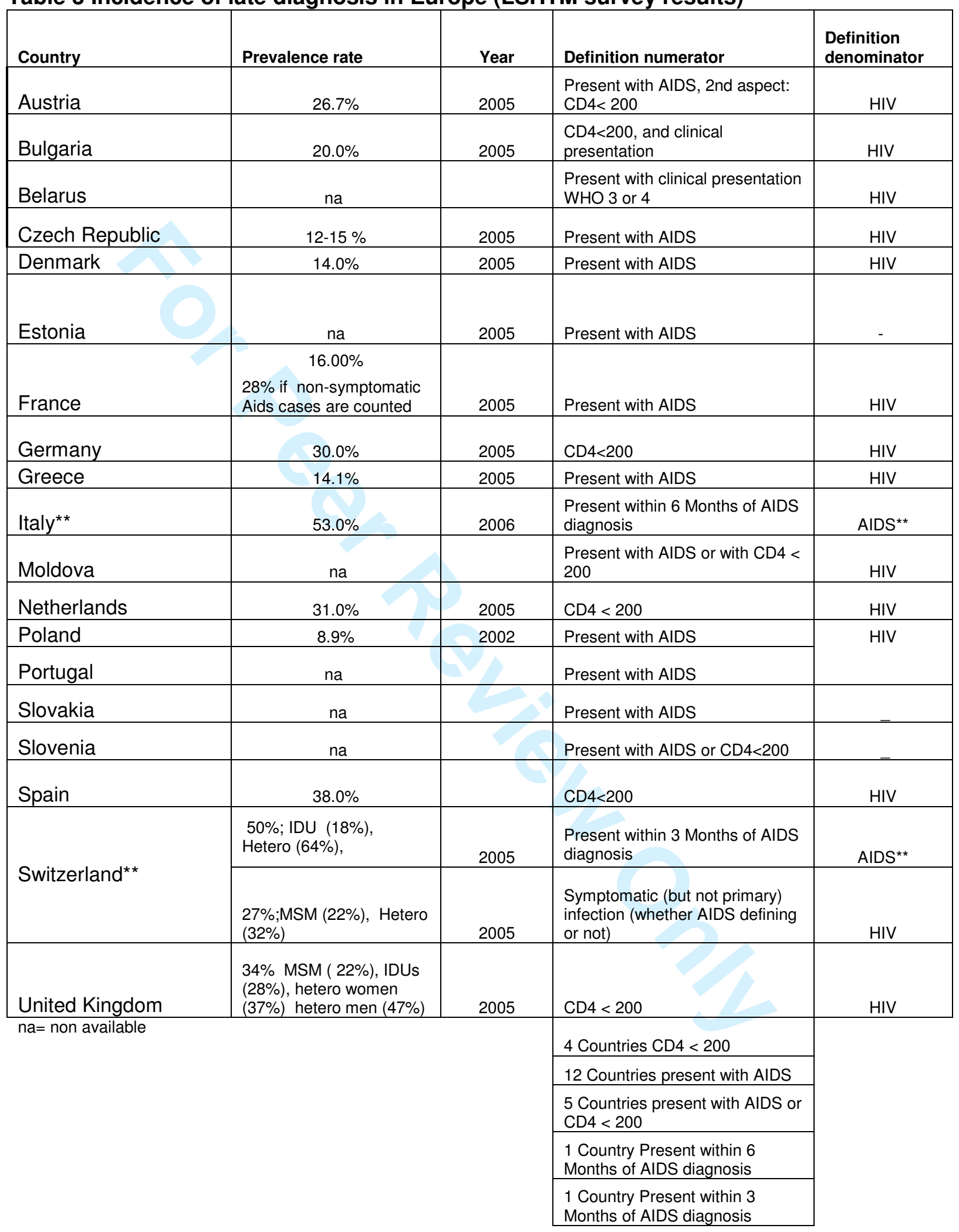

* 33 countries surveyed. 
Responding countries: Austria, Bulgaria, Belarus, Czech Rep, Denmark, Estonia, France, Germany, Greece, Italy, Malta, Moldova, NL, Poland, Portugal, Russian Fed, Slovakia, Slovenia, Spain, Switzerland, UK. Malta and the Russian Fed did not report any information relative to late diagnosis.

Non respondents: Belgium, Cyprus, Finland, Ireland, Latvia, Lithuania, Luxemburg, Romania, Sweden

** in these studies, the \% of late diagnosis is calculated as a proportion of AIDS cases 


\section{$\underline{\text { References }}$}

Baratin, D., Marceillac, E., Trepo, C., Cotte, L., Peyramond, D., Chidiac, C., et al. (2004). Characteristics of patients diagnosed with AIDS shortly after first detection of HIV antibodies in Lyon University hospitals from 1985 to 2001 . HIV Medicine, 5, 273-277.

Barry, S. M., Lloyd-Owen, S. J., Madge, S. J., Cozzi-Lepri, A., Evans, A. J., Phillips, A. N., et al. (2002). The changing demographics of new HIV diagnoses at a London centre from 1994 to 2000. HIV Med, 3(2), 129-134.

BHIVA. (2006). Audit of mortality, http://www.bhiva.org/files/file1001379.ppt\#2.

Boyd, A. E., Murad, S., O'Shea, S., de Ruiter, A., Watson, C., \& Easterbrook, P. J. (2005). Ethnic differences in stage of presentation of adults newly diagnosed with HIV-1 infection in south London. HIV Med, 6(2), 59-65.

Brannstrom, J., Akerlund, B., Arneborn, M., Blaxhult, A., \& Giesecke, J. (2005). Patients unaware of their HIV infection until AIDS diagnosis in Sweden 1996-2002--a remaining problem in the highly active antiretroviral therapy era. Int J STD AIDS, 16(10), 702-706.

Brogly, S. B., Bruneau, J., Lamothe, F., Vincelette, J., \& Franco, E. L. (2002). HIVpositive notification and behavior changes in Montreal injection drug users. AIDS Educ Prev, 14(1), 17-28.

Burns, F., Fenton, K. A., Morison, L., Mercer, C., Erens, B., Field, J., et al. (2005). Factors associated with HIV testing among black Africans in Britain. Sex Transm Infect, 81(6), 494-500.

Burns, F. M., Fakoya, A. O., Copas, A. J., \& French, P. D. (2001). Africans in London continue to present with advanced HIV disease in the era of highly active antiretroviral therapy. AIDS, 15(18), 2453-2455.

Burns, F. M., Imrie, J. Y., Nazroo, J., Johnson, A. M., \& Fenton, K. A. (2007). Why the(y) wait? Key informant understandings of factors contributing to late presentation and poor utilization of HIV health and social care services by African migrants in Britain. AIDS Care, 19(1), 102-108.

Castelnuovo, B., Chiesa, E., Rusconi, S., Adorni, F., Bongiovanni, M., Melzi, S., et al. (2003). Declining incidence of AIDS and increasing prevalence of AIDS presenters among AIDS patients in Italy. Eur J Clin Microbiol Infect Dis, 22(11), 663-669.

Castilla, J., Sobrino, P., De La Fuente, L., Noguer, I., Guerra, L., \& Parras, F. (2002). Late diagnosis of HIV infection in the era of highly active antiretroviral therapy: consequences for AIDS incidence. Aids, 16(14), 1945-1951.

Centers for Disease Control and Prevention. (2003). Late versus early testing of HIV-16 sites, United States, 2000-2003. MMWR Morb Mortal Wkly Rep, 52(25), 581-586.

Chadborn, T. R., Baster, K., Delpech, V. C., Sabin, C. A., Sinka, K., Rice, B. D., et al. (2005). No time to wait: how many HIV-infected homosexual men are diagnosed late and consequently die? (England and Wales, 1993-2002). Aids, 19(5), 513520.

Chadborn, T. R., Delpech, V. C., Sabin, C. A., Sinka, K., \& Evans, B. G. (2006). The late diagnosis and consequent short-term mortality of HIV-infected heterosexuals (England and Wales, 2000-2004). Aids, 20(18), 2371-2379. 
Ciancio, B. C., Forde, J., Dougan, S., Chadborn, T. R., \& Delpech, V. (2006). Trends in mortality and causes of death among HIV-infected individuals diagnosed in the UK: 1993-2004. Paper presented at the Conference Namel. Retrieved Access Datel. from URLI.

Couturier, E., Schwoebel, V., Michon, C., Hubert, J. B., Delmas, M. C., Morlat, P., et al. (1998). Determinants of delayed diagnosis of HIV infection in France, 19931995. AIDS, 12(7), 795-800.

Cu-Uvin, S., Caliendo, A. M., Reinert, S., Chang, A., Juliano-Remollino, C., Flanigan, T. P., et al. (2000). Effect of highly active antiretroviral therapy on cervicovaginal HIV-1 RNA. Aids, 14(4), 415-421.

Delpierre, C., Cuzin, L., Lauwers-Cances, V., Marchou, B., \& Lang, T. (2006). HighRisk groups for late diagnosis of HIV infection: a need for rethinking testing policy in the general population. AIDS Patient Care STDS, 20(12), 838-847.

Delpierre, C., Cuzin, L., \& Lert, F. (2007). Routine testing to reduce late HIV diagnosis in France. BMJ, 334(7608), 1354-1356.

Delpierre, C., Dray-Spira, R., Cuzin, L., Marchou, B., Massip, P., Lang, T., et al. (2007). Correlates of late HIV diagnosis: implications for testing policy. Int J STD AIDS, 18(5), 312-317.

Devaux I, \& Nardone A. (2007). EuroHIV 2006 survey on HIV and AIDS surveillance in the WHO European Region. INVS.

Dodds, J. P., Mercey, D. E., Parry, J. V., \& Johnson, A. M. (2004). Increasing risk behaviour and high levels of undiagnosed HIV infection in a community sample of homosexual men. Sex Transm Infect, 80(3), 236-240.

Duffas. (2006). Missed Opportunities for Earlier Diagnosis of HIV

Infection --- South Carolina, 1997--2005. MMWR Morb Mortal Wkly Rep, 55(47), 12691272.

Easterbrook, P. J., Yu, L. M., Goetghebeur, E., Boag, F., McLean, K., \& Gazzard, B. (2000). Ten-year trends in CD4 cell counts at HIV and AIDS diagnosis in a London HIV clinic. Aids, 14(5), 561-571.

ECDC. (2006). Meeting report, HIV prevention in Europe: Action, needs and challenges, $\begin{array}{llll}\text { Stockholm, } & 2-3 & \text { October }\end{array}$ http://www.ecdc.europa.eu/Health_topics/AIDS/Index.html.

Egger, M., May, M., Chene, G., Phillips, A. N., Ledergerber, B., Dabis, F., et al. (2002). Prognosis of HIV-1-infected patients starting highly active antiretroviral therapy: a collaborative analysis of prospective studies. Lancet, 360(9327), 119-129.

Erwin, J., Morgan, M., Britten, N., Gray, K., \& Peters, B. (2002). Pathways to HIV testing and care by black African and white patients in London. Sex Transm Infect, 78(1), 37-39.

Erwin, J., \& Peters, B. (1999). Treatment issues for HIV+ Africans in London. Soc Sci Med, 49(11), 1519-1528.

Fiore, J. R., Suligoi, B., Saracino, A., Di Stefano, M., Bugarini, R., Lepera, A., et al. (2003). Correlates of HIV-1 shedding in cervicovaginal secretions and effects of antiretroviral therapies. Aids, 17(15), 2169-2176.

Gazzard B on behalf of British HIV Association. (2006). British HIV Association (BHIVA) guidelines for the treatment of HIV-infected adults with antiretroviral therapy. 7, 487-503. 
Giard, M., Gambotti, L., Besson, H., Fabry, J., \& Vanhems, P. (2004). [Factors associated with the late management of HIV-infected patients: literature review]. Sante Publique, 16(1), 147-156.

Girardi, E., Aloisi, M. S., Arici, C., Pezzotti, P., Serraino, D., Balzano, R., et al. (2004). Delayed presentation and late testing for HIV: demographic and behavioral risk factors in a multicenter study in Italy. J Acquir Immune Defic Syndr, 36(4), 951959.

Girardi, E., Arici, C., Ferrara, M., Ripamonti, D., Aloisi, M. S., Alessandrini, A., et al. (2001). Estimating duration of HIV infection with CD4 cell count and HIV-1 RNA at presentation. Aids, 15(16), 2201-2203.

Girardi, E., Sampaolesi, A., Gentile, M., Nurra, G., \& Ippolito, G. (2000). Increasing proportion of late diagnosis of HIV infection among patients with AIDS in Italy following introduction of combination antiretroviral therapy. J Acquir Immune Defic Syndr, 25(1), 71-76.

Gorbach, P. M., Drumright, L. N., Daar, E. S., \& Little, S. J. (2006). Transmission behaviors of recently HIV-infected men who have sex with men. J Acquir Immune Defic Syndr, 42(1), 80-85.

Graham, S. M., Holte, S. E., Peshu, N. M., Richardson, B. A., Panteleeff, D. D., Jaoko, W. G., et al. (2007). Initiation of antiretroviral therapy leads to a rapid decline in cervical and vaginal HIV-1 shedding. AIDS, 21(4), 501-507.

Gupta, S. B., Gilbert, R. L., Brady, A. R., Livingstone, S. J., \& Evans, B. G. (2000). CD4 cell counts in adults with newly diagnosed HIV infection: results of surveillance in England and Wales, 1990-1998. CD4 Surveillance Scheme Advisory Group. AIDS, 14(7), 853-861.

Hamers, F. F., \& Downs, A. M. (2004). The changing face of the HIV epidemic in western Europe: what are the implications for public health policies? Lancet, 364(9428), 83-94.

Hamill, M., Burgoine, K., Farrell, F., Hemelaar, J., Patel, G., Welchew, D. E., et al. (2007). Time to move towards opt-out testing for HIV in the UK. BMJ, 334(7608), 1352-1354.

Health Protection Agency. (2006). HIV/AIDS report: A complex Picture. http://www.hpa.nhs.uk/publications/2006/hiv_sti_2006/default.htm.

Hessol, N. A., Kalinowski, A., Benning, L., Mullen, J., Young, M., Palella, F., et al. (2007). Mortality among participants in the Multicenter AIDS Cohort Study and the Women's Interagency HIV Study. Clin Infect Dis, 44(2), 287-294.

Hocking, J. S., Rodger, A. J., Rhodes, D. G., \& Crofts, N. (2000). Late presentation of HIV infection associated with prolonged survival following AIDS diagnosis-characteristics of individuals. Int J STD AIDS, 11(8), 503-508.

Hogan, C., Dobkin, J., Brudney, K., Chiasson, M., Woodward, M., \& Hammer, S. (2001). Late presentation of HIV disease in the era of potent therapy. Paper presented at the Conference Namel. Retrieved Access Datel. from URLl.

Inciardi, J. A., Surratt, H. L., Kurtz, S. P., \& Weaver, J. C. (2005). The effect of serostatus on HIV risk behaviour change among women sex workers in Miami, Florida. AIDS Care, 17 Suppl 1, S88-101.

Institut National de Veille Sanitaire. (2006). Surveillance de l'infection de VIH-Sida en France, 2005. Bulletin epidemiologique hebdomadaire,, 48. 
Jensen-Fangel, S., Pedersen, L., Pedersen, C., Larsen, C. S., Tauris, P., Moller, A., et al. (2004). Low mortality in HIV-infected patients starting highly active antiretroviral therapy: a comparison with the general population. $A I D S, 18(1), 89-$ 97.

Katz, A., Davis, P., \& Findlay, S. S. (2002). Ask and ye shall plan. A health needs assessment of a university population. Can J Public Health, 93(1), 63-66.

Kayitenkore K, Bekan B, Rufagari J, \& et al. (2006). The impact of ART on HIV transmission among HIV serodiscordant couples. Program and abstracts of the XVI International AIDS Conference; August 13-18, 2006; Toronto, Ontario, Canada. Abstract MOKC101.

Krentz, H. B., Auld, M. C., \& Gill, M. J. (2004). The high cost of medical care for patients who present late (CD4 <200 cells/microL) with HIV infection. HIV Med, 5(2), 93-98.

Lansky, A., Nakashima, A. K., \& Jones, J. L. (2000). Risk behaviors related to heterosexual transmission from HIV-infected persons. Supplement to HIV/AIDS Surveillance Study Group. Sex Transm Dis, 27(8), 483-489.

Likatavicius G, Downs A, Alix J, Devaux i, \& Nardone A. (2006). Late diagnosis in Europe 2000-2004. Institut de Veille Sanitaire.

Longo, B., Pezzotti, P., Boros, S., Urciuoli, R., \& Rezza, G. (2005). Increasing proportion of late testers among AIDS cases in Italy, 1996-2002. AIDS Care, 17(7), 834-841.

Manavi, K., McMillan, A., Ogilvie, M., \& Scott, G. (2004). Heterosexual men and women with HIV test positive at a later stage of infection than homo- or bisexual men. Int J STD AIDS, 15(12), 811-814.

Mayben, J. K., Kramer, J. R., Kallen, M. A., Franzini, L., Lairson, D. R., \& Giordano, T. P. (2007). Predictors of delayed HIV diagnosis in a recently diagnosed cohort. AIDS Patient Care STDS, 21(3), 195-204.

McDonald, A. M., Li, Y., Dore, G. J., Ree, H., \& Kaldor, J. M. (2003). Late HIV presentation among AIDS cases in Australia, 1992-2001. Aust N Z J Public Health, 27(6), 608-613.

Patterson, T. L., Shaw, W. S., \& Semple, S. J. (2003). Reducing the sexual risk behaviors of HIV+ individuals: outcome of a randomized controlled trial. Ann Behav Med, 25(2), 137-145.

Porco, T. C., Martin, J. N., Page-Shafer, K. A., Cheng, A., Charlebois, E., Grant, R. M., et al. (2004). Decline in HIV infectivity following the introduction of highly active antiretroviral therapy. Aids, 18(1), 81-88.

Poznansky, M. C., Coker, R., Skinner, C., Hill, A., Bailey, S., Whitaker, L., et al. (1995). HIV positive patients first presenting with an AIDS defining illness: characteristics and survival. Bmj, 311(6998), 156-158.

Quinn, T. C., Wawer, M. J., Sewankambo, N., Serwadda, D., Li, C., Wabwire-Mangen, F., et al. (2000). Viral load and heterosexual transmission of human immunodeficiency virus type 1. Rakai Project Study Group. $N$ Engl J Med, 342(13), 921-929.

Rosinska, M. (2006). Current trends in HIV/ AIDS epidemiology in Poland, 1999 - 2004. Euro Surveill, 11(4). 
Rotily, M., Bentz, L., Pradier, C., Obadia, Y., \& Cavailler, P. (2000). Factors related to delayed diagnosis of HIV infection in southeastern France. EVALVIH group. Int J STD AIDS, 11(8), 531-535.

Sabin, C. A., Smith, C. J., Gumley, H., Murphy, G., Lampe, F. C., Phillips, A. N., et al. (2004). Late presenters in the era of highly active antiretroviral therapy: uptake of and responses to antiretroviral therapy. Aids, 18(16), 2145-2151.

Samet, J. H., Freedberg, K. A., Savetsky, J. B., Sullivan, L. M., \& Stein, M. D. (2001). Understanding delay to medical care for HIV infection: the long-term nonpresenter. AIDS, 15(1), 77-85.

Samrawickrama A, Leake Date H, Eziefula A, Gilleece Y, Churchill D, \& Fisher M. (2007). Guidelines are only guidelines: individualizing the initiation of highly actvive antiretroviral therapy (HAART). BHIVA, HIV medicine, 8 (supp.1) 10-47.

Saul, J., Erwin, J., Bruce, J. C., \& Peters, B. (2000). Ethnic and demographic variations in HIV/AIDS presentation at two London referral centres 1995-9. Sex Transm Infect, $76(3), 215$.

Sullivan, A. K., Curtis, H., Sabin, C. A., \& Johnson, M. A. (2005). Newly diagnosed HIV infections: review in UK and Ireland. Bmj, 330(7503), 1301-1302.

Vernazza, P. L., Troiani, L., Flepp, M. J., Cone, R. W., Schock, J., Roth, F., et al. (2000). Potent antiretroviral treatment of HIV-infection results in suppression of the seminal shedding of HIV. The Swiss HIV Cohort Study. Aids, 14(2), 117-121.

WHO/UNAIDS. (2007). Guidance on provider-initiated HIV testing and counselling in health facilities. May, http://www.who.int/hiv/en/. 